$$
\begin{gathered}
\text { S sciendo International Conference KNOWLEDGE-BASED ORGANIZATION } \\
\text { Vol. XXVII }
\end{gathered}
$$

\title{
ASPECTS REGARDING THE USE OF BIODEGRADABLE ECOLOGICAL DETERGENTS IN THE DECONTAMINATION OF R.B.C.
}

\author{
Dănuț-Eugeniu MOȘTEANU*, Florin ILIE*, Ruxandra HODIȘ** \\ *"Nicolae Bălcescu" Land Forces Academy, Sibiu, Romania \\ **"'Lucian Blaga" University of Sibiu, Romania \\ dmosteanu@gmail.com, ilieflorinv@yahoo.com, rucsy270392@yahoo.com
}

\begin{abstract}
Ecological decontamination solutions are widely used in various fields of activity especially in this period when many countries in the world are implementing at macro level the concept of sustainable development. The use of detergents in the process of R.B.C. decontamination led to indepth analyzes of the absorbent properties of organic products. These products have the ability to partially or completely remove detergents from wastewater resulting from decontamination, thus reducing pollution by environmental factors. The present paper aimed at the comparative analysis of the absorbent properties of a power plant ash and diatomite ore. Also, some experiments were performed on the biodegradability of detergents considered in the study and the interpolation of data analyzed by spline functions.
\end{abstract}

Keywords: biodegradable, detergent, decontamination, diatoms, volcanic ash

\section{Introduction}

Radioactive contamination is a complex process of depositing small amounts of radioactive substances on surfaces and fixing them through interaction processes (interatomic or intermolecular).

In the decontamination process, physical, physico-chemical and chemical methods are used, which act specifically to remove radioactive products, corresponding to the mechanisms for fixing them on contaminated surfaces.

Physical methods perform radioactive decontamination by vacuuming, spraying, brushing, (in cases of decontamination with substances in the form of dust) steaming, sandblasting, sanding, defoliation (removal of exfoliated paints or varnishes) treatment with absorbent soils, etc.

The mechanism of radionuclide removal by physical decontamination methods is based on the creation of forces capable of overcoming the weak, interfacial connections between them and the contaminated surface. Chemical methods of radioactive decontamination refer to the treatment of contaminated surfaces with solutions of acids, bases, salts, detergents, complexing substances, etc. In this case, chemical reactions take place between the decontamination solutions, radioactive products and the surfaces contaminated by them. In the case of physico-chemical methods, it is used for decontamination, washing with chemicals, detergents, electrochemical treatment.

The scope of the notion of surface active agents or surface-active agents includes a wide variety of chemical compounds that have the property of concentrating on the concentration surface, strongly modifying, even in very small concentrations, the surface properties of liquids in which it dissolves. 
After their various special uses, the surface active agents are divided into detergents, wetting agents, emulsifying agents, foaming agents, etc. All these products have an asymmetric molecular structure, composed of two parts with fundamentally different properties: a non-polar or weakly polar (hydrocarbon) insoluble in water and polar liquids, and a strongly polar (ionizable or non-ionizable)

The accumulation of surface active agents at interfaces (and therefore the strong change in the surface properties of the liquids in which they are dissolved) is due to the asymmetric structure of the molecules, which have different affinities to the phases that make up the system. The more or less condensed state of this layer determines the specific action of the surfactant, respectively of the washing, emulsifying, foaming, soaking agent, etc.

\section{Methodology}

In the first part of the experiment, a comparative analysis of the absorbent properties of a thermal power plant ash and diatomite ore was made. A power plant ash resulting from the burning of lower coals and harvested at electrofilters was used for this purpose.

Following the experiments performed in the chemical and instrumental analysis laboratory, the decrease was observed.

The ash used in the experiment comes from the II thermal power plant, Craiova. Following the experiments performed in the chemical laboratory of the "Nicolae Bălcescu" Land Forces Academy in Sibiu, the decrease of the detergent concentration was observed following the treatment of the ash decontamination solution.
Diatomaceous earth is especially used in the filtration technique, which is a mechanical clarification operation. Diatomite is the petrified remains of microscopic, singlecelled seaweed, composed essentially of silicon dioxide and can be defined as a sedimentary rock.

The aim was to decrease the concentration of the detergent in the decontamination solution, following the absorption on the ash of the thermal power plant or diatomite, the standard method of analysis with methylene blue and formic alcohol was used.

\section{Results and interpretations}

$100 \mathrm{ml}$ of this solution were poured into two Berzelius beakers. In the first glass $50 \mathrm{~g}$ of activated ash was added, and in the second $50 \mathrm{~g}$ of diatomaceous earth. The mixtures were stirred hourly for several hours, after which they were let to rest.

The final concentrations obtained after absorption are:

- $1,10 \%$ for the solution treated with activated ash;

- $0,92 \%$ for the diatomaceous earth solution;

The concentration of detergent remaining after a certain time in the prepared solutions was also monitored, in order to establish the biodegradability of the detergents used in radioactive decontamination. Thus, radioactive decontamination solutions were prepared using detergent $A$ and a biodegradable detergent $\mathrm{B}$ at the initial concentrations of $1.5 \%$, aiming to decrease the concentration over time of the detergents taken in the experiment, table no.1. 
Table no. 1 Decreased detergent concentration as a function of time

\begin{tabular}{|c|c|c|c|}
\hline $\begin{array}{c}\text { Current } \\
\text { no. }\end{array}$ & $\begin{array}{c}\text { Time interval - } \\
\text { hours }\end{array}$ & $\mathbf{C \% ~ A}$ & C\% B \\
\hline 1 & 6 & 1.500 & 1.500 \\
\hline 2 & 12 & 1.443 & 1.432 \\
\hline 3 & 18 & 1.432 & 1.372 \\
\hline 4 & 24 & 1.395 & 1.312 \\
\hline 5 & 30 & 1.384 & 1.198 \\
\hline 6 & 36 & 1.367 & 1.053 \\
\hline 7 & 42 & 1.349 & 0.905 \\
\hline 8 & 48 & 1.329 & 0.832 \\
\hline 9 & 72 & 1.310 & 0.592 \\
\hline
\end{tabular}

From this graph it can be seen that biodegradable detergent biodegrades much faster than type A detergent. The dependence of the detergent concentration in the water was followed, depending on two variables, these being the working time and temperature. The results obtained are specified in the following tables no. 2, 3, 4:

Table no. 2 The temperature for the first data set was $20^{\circ} \mathrm{C}$

\begin{tabular}{|c|c|c|c|}
\hline $\begin{array}{c}\text { Current } \\
\text { no. }\end{array}$ & Time interval - hours & C\% A & C\% B \\
\hline 1 & 6 & 1.50 & 1.50 \\
\hline 2 & 18 & 1.48 & 1.40 \\
\hline 3 & 30 & 1.44 & 1.34 \\
\hline 4 & 42 & 1.40 & 1.26 \\
\hline 5 & 54 & 1.35 & 1.20 \\
\hline 6 & 66 & 1.31 & 1.08 \\
\hline 7 & 78 & 1.27 & 0.91 \\
\hline 8 & 90 & 1.22 & 0.82 \\
\hline 9 & 102 & 1.18 & 0.69 \\
\hline
\end{tabular}

Table no. 3 The temperature for the second data set was $30^{\circ} \mathrm{C}$

\begin{tabular}{|c|c|c|c|}
\hline $\begin{array}{c}\text { Current } \\
\text { no. }\end{array}$ & Time interval - hours & C\% A & C\% B \\
\hline 1 & 6 & 1.50 & 1.50 \\
\hline 2 & 18 & 1.46 & 1.39 \\
\hline 3 & 30 & 1.43 & 1.33 \\
\hline 4 & 42 & 1.39 & 1.24 \\
\hline 5 & 54 & 1.34 & 1.17 \\
\hline 6 & 66 & 1.28 & 0.93 \\
\hline 7 & 78 & 1.25 & 0.84 \\
\hline 8 & 90 & 1.20 & 0.76 \\
\hline 9 & 102 & 1.16 & 0.64 \\
\hline
\end{tabular}


Table no. 4 The temperature for the third data set was $40{ }^{\circ} \mathrm{C}$

\begin{tabular}{|c|c|c|c|}
\hline $\begin{array}{c}\text { Current } \\
\text { no. }\end{array}$ & Time interval - hours & C\% A & C\% C\% B \\
\hline 1 & 6 & 1.50 & 1.50 \\
\hline 2 & 18 & 1.45 & 1.41 \\
\hline 3 & 30 & 1.43 & 1.31 \\
\hline 4 & 42 & 1.37 & 1.20 \\
\hline 5 & 54 & 1.38 & 1.02 \\
\hline 6 & 66 & 1.37 & 0.95 \\
\hline 7 & 78 & 1.34 & 0.79 \\
\hline 8 & 90 & 1.34 & 0.75 \\
\hline 9 & 102 & 1.29 & 0.39 \\
\hline
\end{tabular}

\section{Conclusions}

- Diatomaceous earth has better absorbent properties than activated ash, which recommends it for use in the process of radioactive decontamination;

- Biodegradable detergents have superior properties and are detergents that are removed much faster from the environment which shows us that they have ecological properties.

- The decrease in detergent concentration is much higher in the case of biodegradable detergent than the classic one.

- Diatomite also has the advantage of retaining radioactive substances, considerably reducing radioactive pollution of water and soil.

- As a result of operations performed with radioactive isotopes, unavoidable contamination occurs in nuclear units. This has made it possible to test a wide range of radioactive decontamination substances and compositions, and their effectiveness can be seen.

- Having these substances and compositions tested practically, it can be seen which is best suited to the military field, a field that has its peculiarities: large decontamination surface, materials that can be easily oxidized, etc. Therefore, the aim was to use cheap substances, with limited corrosive action, easy to prepare and highly effective in decontamination. With a minimum of resources to achieve maximum efficiency.

- As seen, these are solutions of various detergents with or without additives $(\mathrm{Na}$ hexametaphosphate, $\mathrm{Na}$ carbonate) that remove radioactive substances from the surfaces of interest.

- It is a cheap way to reduce soil pollution.

\section{References List}

[1] Otrisal, P., Melicharik, Z., Svorc, L., Bungău, S., Virca, I., Bârsan G., Moșteanu, D., Testing Methods of Assessment for the Chemical Resistance of Insulating Materials Against the Effect of Selected Acids, Revista de materiale plastice, 2018, vol. 54. No. 4, pp. 547. ISSN 0025-5289. IF 0,778.

[2] Otrisal, P., Florus, S., Svorc, L., Bârsan, G., Moșteanu, D., A New Colorimetric Assay for Determination of Selected Toxic Vapors and Liquids Permeation Through Barrier Materials Using the Minitest Device. revista de materiale plastice, 2017, vol. 54. No. 4, pp. 750. ISSN 0025-5289. IF 0,778. 
[3] Moșteanu, D., Mihăilă-Lică, G., M., Halmaghi, E.E, Moșteanu, D., The sustainable development-human development. Revista Academiei Forțelor Terestre, Date of publication: 2014, Volume (number): 1(73), p. 112.

[4] Savu, I., Moșteanu, D., Bazele decontaminarii radioactive, chimice și biologice Vol I, Editura Academiei Forţelor Terestre, Sibiu, 2010, ISBN 978-973-153-065-9; 